\title{
Governance for Learning Outcomes in European Policy- Making: Qualification Frameworks Pushed through the Open Method of Coordination
}

\author{
Odd Bjørn Ure \\ Consultur. Studies\&Analyses \\ Rosenborggata 13c \\ 0356 Oslo, Norway \\ E-mail: oddbure@gmail.com
}

\begin{abstract}
The construction of European education policy builds on a widely shared goal of transparency in qualifications, upheld by the popular narrative of mobile students endowed with scholarships from the EU Erasmus programme, which allow them to transfer credit points between universities and across national borders. EU education policy is increasingly inscribed in National Qualification Frameworks (NQF). Their European umbrella is coined the European Qualification Framework (EQF), which is linked to a discourse on or even shift to Learning Outcomes; functioning as a tool for the displacement of input to output categories in education systems with a view to make qualifications more transparent. This form of governance situates Learning Outcomes as a tool for policy reform that intentionally should affect all educational and administrative levels of European education. The article shows that the multitude of governance instruments used to promote a shift to Learning Outcomes are so varied that EU education policy has no apparent need of new instruments for this purpose. The fact that Learning Outcomes are linked to EU policy instruments of the Open Method of policy-Coordination and destined for several sectors of education, increases the likelihood that they will be translated into modified learning practices. Yet, there is a danger that governance of Learning Outcomes succumbs to a pitfall of declaratorily placing Learning Outcomes in the middle of learning practices in all subsectors of education, without sufficiently proving their real novelty and regulatory functions.
\end{abstract}

Keywords: Qualifications Frameworks, EU Policy Coordination, Learning Outcomes, Governance, Knowledge Production 


\section{Bibliographical notes:}

Odd Bjørn Ure, cand. polit. from the University of Bergen (Norway), is independent researcher and consultant in his own firm, Consultur (www.consultur.no). His main research interests is comparisons of education, training and labour market systems.

\section{Acknowledgements:}

I am very grateful for the instructive comments provided to earlier versions of this article by José Luis Garcia Molina (Madrid) and Gerhard Geiger (Vienna). 


\section{Introduction}

Today's public policies for education and training at national and EU level seem increasingly geared towards efforts to spur Learning Outcomes. One example is the 2012 Communication from the Commission on Rethinking Education, with the message that education and training can only contribute to growth and job-creation if learning is focused on outcomes through the learning process, rather than on completing a specific stage or time spent in school. The EU agency Cedefop ${ }^{1}$, which is extensively used for analysing and monitoring progress in what is said to be a shift towards learning outcomes, defines this study object as statements on what a learner knows, is able to do and understands following completion of learning (Cedefop 2009).

The notion of learning outcomes has been investigated in several articles and is subject to substantial debate. According to Souto-Otero (2012), today's most popular account of learning outcomes heralds them as a tool for policy reform. Learning outcomes are therefore believed to solve problems of transparency, quality, accountability and efficiency; whereas they provide precision and avoid overlaps or repetition in learning. It could be added that this account is also the one frequently cheered by educational policy makers.

The EU agenda on education and training comprises policy instruments, particularly the European Qualification Framework, which is nurtured by and/or replicated in national qualification frameworks. This raises the question of intersections between national and cross-national policy-making. Papadopoulos (2010) claims for example that with 'downwards' devolution and decentralisation, coupled to 'upwards' Europeanisation, - today's governance frequently relates to 'multi-levelness'. He holds that this blurs the centre-periphery divide and correlates with network governance.

The article argues that better insight in learning outcomes depends on analysing their introduction from a governance perspective, notably how they are aligned to the EU Open Method of policy Co-ordination. The following questions will be discussed:

1. How can theories on knowledge production inform analyses of governance of Learning Outcomes and qualification frameworks at a national and European level?

2. The de facto inclusion of the Learning Outcome discourse in the Open Method of policy-Coordination accentuates network forms of governance and multi-level policy-making: how can this pattern regulate the involvement of societal actors and interest groups affected by this discourse?

3. Which governance instruments are being used for promoting the shift to Learning Outcomes?

4. What does the usage of such governance instruments reveal about the possibility that the aims behind the proclaimed shift will be reached?

The article is based on analyses of literature addressing these topics, supported by reports from EU institutions taking stock of how EU policies in the field of education and training are advancing.

European Centre for the Development of Vocational Training. 


\section{Governance of knowledge production}

Inspired from theories about professions and occupations, the term 'governance' can denote a panoply of mechanisms for steering, control, self-regulation and professional or occupational autonomy. One example of the latter is the relative autonomy of teachers in practicing their work, including how the introduction of frameworks for learning outcomes (e.g. NQFs and the EQF) could change teachers' professional agency and teaching practices in general. This raises the question of how an occupation controls its own knowledge production to the point of resembling a classical profession. Julia Evetts has contributed to the latter debate by warning against a sharp distinction between occupational and professional control mechanisms (cf. Evetts 2003; 2011).

Among the educational disciplines, the introduction of learning outcomes particularly intervenes in pedagogy and didactics. In the prolongation of these disciplines, some psychological theories clearly address organisational processes that foster learning at the workplace and the formation of learning goals. Seen together, these two processes could contribute to the constitution of governance mechanisms. Activity theory inspired by Lev Vygotsky intervenes in this discourse. A German proponent of this theoretical strand, Joachim Lompscher, views learning as transmission; in the meaning of formation of learning goals and students' understanding of what they need to acquire during their learning activities (Joachim Lompscher 1999, 2004).

A Finnish proponent of the same strand, Yrjö Engeström, underlines that the outcomes of (workplace) learning are "expanded objects and new collective work practices, including practices of thinking and discourse". He argues that the "system view" of an organisation is blatantly insufficient for understanding and facilitating qualitative changes at the workplace. He therefore holds that the work organisation must "be translated back into a workplace inhabited by human beings.” (Engeström and Kerosuo 2007). We will come back to this tension between system and learners (human beings) in the next subchapter, which is devoted to governance and possible alienation mechanisms in EU policy-making.

The 2009 report from Cedefop on learning outcomes refers to a shift from providers to learners and employers. To take this point further, among the providers are educational institutions with their professions built around academic disciplines. We may therefore see a transition from educational disciplines into multidisciplinary approaches where knowledge is generated in a context of application and social accountability. This is the perspective in a theory on the transition from mode 1 to mode 2 of knowledge production, as developed by Gibbons et al. in their book "The new production of knowledge: the dynamics of science and research in contemporary societies" (1994) and later followed up in Nowotny, Scott and Gibbons (2001) ${ }^{2}$. This perspective is however more than a theoretical intervention because the authors admit it to be a "project" (Nowotny et al. 2003); a clarification which could be amplified by Helga Nowotny's continued efforts to promote EU research policy when heading the European Research Advisory Board and later the European Research Council.

In an analysis of such intertwining of theoretical analyses and political projects, Nick Stehr (2003, p. 652) holds that the organisation of the public sphere is changing so that participatory demands and contribution to the regulation of knowledge become more routine

2 Re-thinking Science. Knowledge and the Public in an Age of Uncertainty. 
“...more generally, we will see significant transformations of the political culture and the re-alignment of the major institutions of modern society as the result of the emergence of knowledge politics as a new field of political activity".

One advantage of analysing learning outcomes from a governance perspective is that it illustrates internal as well as external processes of knowledge production. The multitude of theories on and assumptions of our contemporary information or knowledge society complicates the task of situating a possible shift to learning outcomes within theories on knowledge production. As suggested by Bernard Paulré (2001), the real interest for the research agenda is to look for possible changes in governance structures emanating from new forms of accumulation of knowledge. We will revert to this point in the discussion below on networks of expertise and epistemic communities.

Several authors claim that knowledge production is becoming more external and that less discretion is exercised by professions, for example those found in education and training institutions. In an extensive literature review, Laurens $\mathrm{K}$. Hessels and Harro van Lente (2008) assess the extent to which fellow scholars share the basic assumptions in the theory on new production of knowledge. Proponents of theories on Innovation systems, Academic capitalism, Postacademic science and the Triple-Helix model (the three are State-AcademiaBusiness); all address a turn towards research activities more relevant for immediate applications and the short-term policy agenda. Consequently, this literature tends to converge on pointing at more interactive relationships between science, industry and government; most clearly outlined in the Triple-Helix model. On this point, we therefore see congruence between the theories on knowledge production and the discourse on learning outcomes. The former are however criticised in several scholar works. Fuller (1995) distances himself from "Michael Gibbons and his band of the multinational, policy-oriented theorists" and claims that:

"Mode 2 is less the permeation of industrial society by knowledge-based values and more the permeation of knowledge-based communities by industrial values”.

Furthermore, Hessels and van Lente (2008) underscores that the generality of the arguments sustaining some contributions to the theory on new production of knowledge is often challenged, including the question of how the rise of new modes of quality control affects the knowledge production. As illustrated in the next section, this last point is often cited in the literature on EU governance. From that corner, EU policymaking is frequently criticised for promoting a governance model introducing pervasive checks of audit, appraisal and accountability.

\section{All Governance and alienation in EU policymaking?}

The following section of the article briefly introduces how the term governance is used in very critical interpretations of how EU policy is developed and disseminated.

According to Enroth (2014), the concept of governance became during the 1990s equated with policy-making by network, and the network concept became the privileged term in an ideal-typical trichotomy of forms of governing within the modern welfare state: hierarchies, markets and networks. Similarly, the state becomes a "collection of intergovernmental networks made up of governmental and societal actors with no sovereign actor able to steer or regulate". 
Shore (2011) writes that the term governance is increasingly used to convey the complexity of modern political systems in which power is spread across multiple sites. Moreover, policy-making is the result of negotiation and interaction between numerous national and supranational actors and institutions. This is said to explain the popularity of the term 'multi-level governance' as a label to describe the EU's evolving political regime.

Shore criticises a European Commission White Paper on good governance (2001) for being primarily defined in economic terms, such as 'efficiency,' 'effectiveness,' 'better policy making,' and better regulation'. He argues that the EU model of European governance emphasises informal instruments of regulation and self-regulation, in a kind of 'organic democracy' based on the rule of experts and the application of new public management techniques. Moreover, policymaking becomes the privilege of non-elected experts, technocrats and 'organisational citizens' (ibid.).

According to Papadopoulos (2010), this interactivity suggests a form of governance characterised by co-operative relations in policy-making between public and non-public actors. This means that policies are formulated or implemented by networks involving public actors (politicians and administrators), together with non-public actors of different nature (firms, interest representatives and stakeholders as well as experts).

In a proposal for a "grammar of governance", Jane Mulderrig (2011) summarises literature warning that the Social State gives way to the Enabling State. This shift in mode and style can briefly be characterised as a move from 'government' to 'governance'. Centralised hierarchical control is (partially) relinquished in favour of hierarchies of dispersed power and 'responsible autonomy'. With the dispersal of power comes greater emphasis on individual responsibility and autonomy. She holds that this responsibility is not founded on trust because it is eroded by pervasive checks of audit, appraisal and accountability.

According to Mulderrig, this new 'soft' mode of governance therefore requires a two-fold move: the government must step back from direct control over actions (but still retains the power to specify outcomes), while the "responsible individual" is allowed to step forward. This means that 'enabling' individuals has become a key feature of governance, such as witnessed by the educational policies for enabling citizens to become lifelong learners and take more responsibility of their own learning.

\section{Networks and multi-level governance in the field of education and training}

Romuald Normand (2010) proposes an angle for understanding governance in education akin to that of Nowotny, Scott and Gibbons, referred to above. He holds that science and policy are not in a discontinuing relationship. Through the elaboration of instruments and methodologies of measurement, they rather represent a corpus of scientific knowledge and normative principles shared by representatives of supranational organisations and nation states. International networks of expertise, set up for developing educational indicators, tend to swift the location of dissemination and circulation of knowledge from the scientific to the policy area. The way in which this expertise is framed and translated along scientific networks, allows for a mapping of groups of experts by using the concept 
'epistemic communities'; meaning a constellation of beliefs, values and methods shared by members of the same community. These members agree on common principles about the validity of their knowledge with regard to different interest groups and policy-makers. In the same vain, Papadopoulos (2010) holds that governance networks only offering consultative advice can be called 'epistemic communities', characterised by a lack of formal authorisation.

In his article analysing two networks of experts set up by the EU DirectorateGeneral for Education and Culture ${ }^{3}$, Normand (2010) claims that such expertise contributes to the production of indicators and benchmarks supporting the Open Method of policy Co-ordination (OMC). The expertise is inscribed in a policyborrowing process and the transfer of knowledge between several agents and institutions at a global level, such as the OECD. Normand holds that the European Commission uses such "epistemic communities" not only because of the importance attached to education policies by interest groups and the general public, but also to alleviate the uncertainty of trade-offs with EU Member States.

Deliberation, bargaining and compromise-seeking is the main modus operandi of network forms of governance. Although such networks may formally have no binding decision-making power, information is exchanged between them so that they acquire a co-ordinating function and are expected to favour crossnational convergence on policy practice. Normand (2010) draws on recent empirical research and concludes that networks deliver a variety of outputs, - such as decisions, standards, or merely knowledge.

In the view of Papadopoulos (2010), network and multi-level governance is characterised by more accountability, but less democracy. He claims that traditional regulatory instruments today coexist or compete with newer cooperative or voluntary instruments. Multi-levelness, which blurs the centreperiphery divide, is correlated with network governance, which blurs the statesociety divide. Part of the reason is that in order to prove the authenticity of their representational claims, subnational governments have an interest in showing that they stand close to civil society actors.

The view that networks and multi-levelness are closely related is shared by Enroth (2014). For him, multi-levelness means that policy-making requires the cooperation of distinct governmental levels (local, subnational/regional, national, European, transnational), in a kind of multi-level government. EU structural and regional policies are said to exemplify multi-level governance, whereas they combinedly reside on co-operation of public actors across levels as well as cooperation with non-public actors in partnership forms. Below, we will make the point that EU education policies can be added as one more example of such governance.

\section{Governance instruments of the Open Method of policy-Coordination applied to Learning Outcomes}

Rather few research contributions covering EU governance of education and training go beyond ideological analyses of the political messages that EU institutions are said to convey or give preference to when making use of governance instruments. Below, we have tried to identify the most promising contributions to this discussion and we ask the following question:

3 The Network of Experts in Social Sciences of Education and Training (NESSE) and the European Expert Network on Economics of Education (EENEE). 
How do Learning Outcomes play out in policies for transforming education and training and what is the role of the Open Method of policy-Coordination (OMC) with regard to Learning Outcomes?

The proclaimed shift from learning input to learning outcomes (CEDEFOP 2009) is brought about by the OMC. The latter reflects a change in policy style or a shift from 'government' to 'governance' (Papadopoulos 2010). Lange and Alexiadou (2007) identify three key characteristics of the Open Method of policy Co-ordination: its flexibility, its reflexive nature when relying on 'soft law' and its preference for "New Public Management tools of objectives, benchmarks and indicators".

This softness contrasts with the traditional vertical dimension implicit in the supra-national and inter-national dynamics of formal transfer of legal competences, notably what Borrás and Jacobsson (2004) call the hierarchical nature of their administration and judicial enforcement. Papadopoulos (2010) explains that traditional regulatory instruments today coexist or compete to a varying degree with newer cooperative or voluntary instruments. The soft governance instruments accentuate the transnational dimension of European integration. In other words, these instruments "convey further dynamism to the forms and contents of crossborder interactions in the EU at all levels” (Borrás and Jacobsson 2004).

The literature on the OMC and soft policy-making often makes use of examples from certain policy areas that illustrate how such policy is shaped. For example Paster (2005), harvests from studies of how the EU European Employment Strategy was implemented. Borrás and Jacobsson (2004) holds that in specific policy areas close to the welfare-state core issues (e.g. social policy, employment policy and taxation), the thrust in soft governance instruments might be a first step towards a more substantive EU regulatory and binding sets of measures. In the field of education, and particularly with regard to Learning Outcomes, it is however unlikely that binding measures will be deployed. The reason is that EU interventions in this policy area for decades have been contested by many Member states (cf. Holford and Mleczko 2013). It appears that the close connection between nation building, the political art of forging national identities and the utility of the school system for this purpose; are all factors that tend to restrict the deployment of EU regulatory measures in this realm.

This restriction can be conceptually aligned with the subsidiarity principle, which calls for implementation of EU activities and measures at the closest level to those affected by them. For example, training for strengthening local or regional belonging and citizenship should be regulated at a decentralised level. One consequence of this maxim is that the Member states were adamant in designing the most recent EU programme for education and training, Erasmus+, in a way channelling more money from centralised actions in Brussels to national agencies in each Member state.

Cedefop, which assists EU institutions and member states in realising a shift to Learning Outcomes, makes clear that such outcomes are written for a number of purposes: descriptors in qualifications frameworks, standards for qualifications, assessment standards and curricula (cf. Cedefop 2013b). The Cedefop definition reflects the political framework in which learning outcomes are embedded, notably the link to qualification frameworks. Learning outcomes therefore sustain the implementation of European and national education policies by means of the policy instrument ECTS in the sector of higher education and the European Credit system for Vocational Education and Training (ECVET), both related to the European 
Qualification Framework ${ }^{4}$. The ongoing monitoring of ECVET (cf. Cedefop 2013a) confirms that this EU policy instrument is:

“....a tool designed to aid the transfer, recognition and accumulation of learning outcomes of individuals on their way to achieving a qualification. ECVET readiness requires that qualifications are described in terms of learning outcomes, and that these are grouped into units that might provide credits (and points) to create individual learning paths.”

The fact that Learning Outcomes are linked to policy instruments destined for several sectors of education increases the likelihood that they will gain ground and be translated into modified learning practices. In the next section, we will further discuss the various governance instruments that the OMC can lean on when instigating a shift to Learning Outcomes.

\section{Governance instruments for promoting a shift to Learning Outcomes}

So far, and to paraphrase Arrowsmith et al. (2004), the European Commission (EC) seems to prefer 'loose learning networks' generating 'improvement-oriented benchmarking' within a 'consensual exercise' in line with the Open Method of policy Co-ordination. Hence, the emerging Commission method for the pursuit of learning outcomes can be called 'reflexive' and 'regulated self-regulation', while relying on "the elaboration of customized local solutions within a guiding framework of principles and a process of monitoring and review"

This means that the EC mainly tends to launch Call for Tenders inviting researchers and analysts to conduct thematic studies. The ensuing results are then presented to stakeholders, such as social partners and representatives from national ministries ${ }^{6}$. A study on learning outcomes launched by Cedefop in 2013, for example delves into teacher training in order to better understand how the learningoutcomes approach influences education and training practices ${ }^{7}$.

Two years later, Cedefop launched a new Call for Tenders inviting for analyses of how the learning-outcomes approach serves as a tool for better dialogue between initial vocational training and the labour market, including institutional support mechanisms. This Call demonstrates very well the high ambitions behind a shift to learning outcomes, whereas it addresses the definition, review as well as renewal of learning outcomes. Moreover, the alignment of assessment practices with intended and actual learning outcomes is to be covered. Finally, the use of Learning-Outcome approaches will be demonstrated in the definition of new educational and qualifications standards and as well as the revision of curricula. It is therefore difficult to identify one single aspect of initial

$4 \quad$ According to Garcia Molina (2011), in the package of community instruments that the EU has started to deploy during the implementation of a European Qualification Framework, - count ECVET, the European Common Principles for validation of non-formal and informal learning, EUROPASS and ESCO (European classification of Skills, Competences and Occupations).

5 cf. the discussion of the Open Method of Policy Co-Ordination by Arrowsmith et. al 2004, $323 f f$.

6 Cf. http://www.cedefop.europa.eu/events/LearningOutcomes-2013/index.html.

7 See the Cedefop open invitation to tender \# AO/ECVL/JB-SPEV/LearningOutcomes/004/13. 
vocational training that slips away from this upcoming analysis of Learning Outcomes in one subsystem of education and training ${ }^{8}$.

Apart from benchmarking, all other governance instruments listed by authors who address the OMC, imply a more or less pronounced role for civil society actors (Papadopoulos 2010). Among these instruments count co-regulation, negotiated agreements or voluntary codes of conduct, - in addition to policy borrowing, exchange of best practices and mutual policy learning. Some researchers even tend to consider the OMC as cross-national policy learning (cf. Paster 2005).

Among other governance instruments than networks that can be aligned to the Open Method of policy Co-ordination when applied in education and training, count Communities of Practice (cf. Etienne Wenger 1998) i.a. used for advancing the EU agenda on non-formal and informal learning (cf. Bjørnavåld 2001) as well as ECVET ${ }^{9}$. In order to move forward the ECVET agenda, it has also been proposed to conclude Memoranda of Understanding between countries and regions (Garcia Molina 2011).

Moreover, Zones of Mutual Trust (ZMT) are proposed as a general approach for discussing and implementing qualification frameworks. Garcia Molina (2011) comments that transparency of qualifications presupposes mutual confidence, and he points out that ZMTs could lay the ground for this. He holds that ZMTs around qualification frameworks partly resembles the notion Communities of Practice. We could add that Normand's term 'epistemic communities' being constituted by beliefs, values and methods shared by members of the same community; could function in a similar way.

Although the real difference between these governance instruments appears minor, Zones of Mutual Trust could denote more structured approaches leading to agreements between organisations with the aim to construct frameworks of recognition building on the eight reference levels of the EQF. The official EU stance is that learning outcomes change the understanding of qualifications and degrees by linking them to the descriptors Knowledge-Skills-Competences. These descriptors are used for the eight levels on which the EQF rests. Learning Outcomes are meant to capture specific combinations of qualifications, including theoretical knowledge as well as practical and technical skills alongside social competences. Qualifications are understood as the formal results of assessment and validation processes for which a competent body rules that a person's learning outcomes fulfil certain standards (cf. Dunkel and Le Mouillour 2013).

\section{The Open Method of policy-Coordination and stakeholder involvement in the foundation of Learning Outcomes}

Organised interests in the field of education and training are often coined stakeholders by the EU jargon. In line with the theory and project of open knowledge production described at the beginning of this article, the current promotion of Learning Outcomes in qualification frameworks complies with

8 CEDEFOP Open Invitation to Tender, Contract notice 2015/S 092-164546 of 13/05/2015.

9 The headline for the third annual ECVET forum arranged by Cedefop (2012) was for example "Taking the next step: Building the ECVET community of practice". 
attempts to involve a range of internal and external stakeholders in knowledge production within societal sectors such as research, higher education and vocational training.

This goes hand in hand with a process of decentralisation implying more responsibility to lower levels, including citizens and individual learners. Governance theory inscribes this process in "network governance", where the end point is citizens, or rather 'enabling' individuals, - meaning that everyone - with some external support - should take more responsibility of their own learning; to the point of becoming lifelong learners. Learning Outcomes are meant to assist learners on this trajectory. Hence, together with a persistent push 'from above' for introducing learning outcomes, in view of their pivotal role in constructing qualification frameworks, - the work mode of Learning Outcomes bears some signs of introducing them from below; as witnessed by a CEDEFOP seminar devoted to three cases from the crafts, industry and service sectors. The event was labelled a "Policy learning forum on the definition and writing of learning outcomes for VET qualifications" 10 (September 2015), convening experts as well as "other stakeholders including Social Partners directly involved in the definition, writing and review of learning outcomes for VET".

We could seek inspiration in another strand of thought in order to further explain the dual sides of Learning Outcomes governance, namely the theorisation of new(er) management principles in public administrations (NPM). In this regard, Michelsen et al. (2016) suggest that the introduction of "management by objectives and results", with ensuing indicators, is becoming pragmatic and increasingly flexible, while referring to Lægreid, Roness and Rubecksen (2008). Hence, crosscountry studies of policies for Learning Outcomes in higher education point at loosely integrated higher education systems with weak ties between policy instruments and indicators, as well as a weak relation between indicators and governance of the overall policy for higher education (Michelsen, S., Sweetman, R., Stensaker B., and Bleiklie I.: The shaping of a policy instrument: The politicaladministrative formation of learning outcomes in higher education in Norway and England, to be published in 2016).

This demonstrates the dual side of New Public Management (NPM) applied to the educational sector, in the sense that it also consists of a decentralising tendency of allocating power from ministries to each school and to the parents, while instigating the "sage teacher" to step down from the stage to become a facilitator of learning for students who are constructing their own learning environments (cf. Skarpenes 2007). Central processes in this shift could be aligned with the prevalence of child-centred pedagogy (pedocentrism), leading to a concurrence of NPM principles of decentralisation and a concept of knowledge accruing from an absolutisation of pupils' immediate learning experiences (cf. ibid). Particularly the introduction of Learning Outcomes at multiple levels, makes it relevant to watch out for such unexpected and perhaps contradictory concurrences in the policy landscape of outcome indicators.

\section{Conclusions}

The preceding passage between theoretical contributions and empirical observations allows for a preliminary summary of which governance instruments

\footnotetext{
10 See http://www.cedefop.europa.eu/en/events-and-projects/events/policy-learningforum-definition-and-writing-learning-outcomes-vet.
} 
are used for promoting a paradigm of Learning Outcomes in view of their close relation to national and EU qualification frameworks. Our discussion of governance instruments for promoting Learning Outcomes has revealed the following instruments:

\begin{tabular}{|l|c|c|c|}
\hline \multicolumn{4}{|c|}{$\begin{array}{l}\text { Governance instruments (GI) for promoting Learning Outcomes (LOs); } \\
\text { often related to the Open Method of policy }\end{array}$} \\
\hline & $\begin{array}{l}\text { The GI mainly } \\
\text { appears as a } \\
\text { political or } \\
\text { academic notion }\end{array}$ & $\begin{array}{l}\text { The GI is } \\
\text { particularly } \\
\text { used for } \\
\text { promoting LOs }\end{array}$ & $\begin{array}{l}\text { A general GI } \\
\text { within the OMC }\end{array}$ \\
\hline experts groups & & $\mathrm{x}$ & \\
\hline epistemic communities & $\mathrm{x}$ & $\mathrm{x}$ & $\mathrm{x}$ \\
\hline communities of practice & & $\mathrm{x}$ & $\mathrm{x}$ \\
\hline Zones of Mutual trust & & $\mathrm{x}$ & $\mathrm{x}$ \\
\hline Memoranda of Understanding & & $\mathrm{x}$ & $\mathrm{x}$ \\
\hline exchange of good practices & & & $\mathrm{x}$ \\
\hline $\begin{array}{l}\text { deliberate policy borrowing based on } \\
\text { what works in other countries }\end{array}$ & & & \\
\hline $\begin{array}{l}\text { exploratory seminars/conferences of } \\
\text { mutual policy learning }\end{array}$ & & & \\
\hline $\begin{array}{l}\text { structured mutual policy learning } \\
\text { exercises }\end{array}$ & & & \\
\hline
\end{tabular}

As can be interpreted from the table above, the multitude of governance instruments observed are so varied that the EU policy of promoting learning outcomes has no apparent need of new instruments. All instruments cannot be classified as top-down, as sometimes suggested in the bleakest accounts of EU policy-making referred to at the beginning of the article. Some of them are not particularly targeted for educational expertise from academia, and could therefore serve in the mobilisation of organised interests (interest groups) into discussions and, possibly, joint development work on the road towards an education system systematically structured by learning outcomes. Among these instruments count exploratory seminars, conferences of mutual policy learning, Zones of Mutual Trust and, partly, exchange of good practices.

More than sorrows about the involvement of stakeholders, it is precisely an insufficient permeation of learning outcomes that is flagged in stock-taking reports of the progress made in this regard:

"While the learning outcomes approach is already the basis of the European Qualifications Framework and national qualification frameworks, this fundamental shift has not yet fully percolated through to teaching and assessment” (EC 2012b, 7).

There is even some satisfaction as to how much learning outcomes are embedded by those concerned:

"The processes leading up to... (national qualifications) frameworks (the author's amplification) have generally been inclusive and involved a broad group of stakeholders in a concrete discussion on how to describe and apply learning outcomes. (...) However, (....) some doubt remains regarding the 'deeper' impact of learning outcomes, notably 
on assessment forms and teaching and training practises" (Cedefop 2013b, 2f).

Learning Outcomes belong to qualification frameworks functioning as soft policy instruments according to the Open Method of policy Co-ordination, which contains many mechanisms for influencing policy-making. The pertinence of making soft steps in this policy landscape may be justified by all variations in what is reported as Learning Outcomes in stocktaking reports ordered by European Commission services. The huge variety of approaches for applying Learning Outcomes in qualification frameworks point in the same direction. As demonstrated by Garcia Molina (2011), the learning outcomes of the European Qualification Framework function as a tool for arranging various parts of the entire framework by displacing input to output categories with a view to make qualifications more transparent.

The systematic work of EU institutions and agencies to promote a "shift to Learning Outcomes" does not seem to change the Open Method of policy Coordination such as it until now has been applied in the field of education and training. The fact that Learning Outcomes are linked to policy instruments destined for several sectors of education, increases the likelihood that they will gain ground and be translated into new or modified learning practices. Yet, six years after the proclaimed shift to learning outcomes, it is too early to judge whether the governance instruments for promoting this shift are sharp enough or are being applied in a way that allows the multi-levelness of governance to play out. In other words, when the introduction of Learning Outcomes affect multiple administrative levels as well as stakeholders that underpin the corresponding administrative structures; the utility of the governance instruments is reflected in their ability to translate into non-declaratory local practices. The aim of making qualifications more transparent is widely shared at all these levels. This simple fact could be a point of departure for a revamped form of multi-level dialogue on Learning Outcomes. 


\section{References}

Arrowsmith, J., Sisson, K., \& Marginson, P. (2004). What can 'Benchmarking' Offer the Open Method of Co-ordination. Journal of European Public Policy, 11(2), 311-328.

Bjørnavåld, J. (2001). Making learning visible: identification, assessment and recognition of non-formal learning. Thessaloniki: European Communities.

Borrás, S., \& Jacobsson, K. (2004). The Open Method of Coordination and the New Governance Patterns in the EU. Journal of European Public Policy, 11(2), 185-208.

Cedefop (2009). The shift to learning outcomes: policies and practices in Europe. Cedefop Reference series No 72:

http://www.cedefop.europa.eu/etv/Upload/Information_resources/Book shop/525/3054_en.pdf. Accessed 30 December 2013.

Cedefop (2010). Learning outcomes approaches in VET curricula. A comparative analysis of nine European countries. Research Paper No 6: http://www.cedefop.europa.eu/EN/Files/5506_en.pdf. Accessed 30 December 2013.

Cedefop (2012a). Curriculum reform in Europe: the impact of learning outcomes. Research paper No 29:

http://www.cedefop.europa.eu/EN/Files/5529_en.pdf. Accessed 30 December 2013.

Cedefop (2012b). Analysis and overview of NQF developments in European countries: annual report 2012. Cedefop working paper No 17: http://www.cedefop.europa.eu/EN/Files/6117_en.pdf. Accessed 30 December 2013.

Cedefop (2013a). Monitoring ECVET implementation strategies in Europe. Cedefop Working paper No 18: http://www.cedefop.europa.eu/ EN/Files/5537_en.pdf. Accessed 30 August 2014.

Cedefop (2013b). The shift to learning outcomes and its impacts: taking stock of European policies and practices. Conference documents. http://www.cedefop. europa.eu/events/LearningOutcomes-2013/index.html.

Accessed 30 December 2013.

Cummings, W.K. (2003). The Institutions of Education - a comparative study of educational development in the six core nations. Oxford: Symposium Books.

Dunkel, T., \& Le Mouillour, I. (2013). Berufsbildung auf höchstem Niveau europäische Erfahrungen. In E. Severing, \& Teichler, U. (Eds.), Akademisierung der Berufswelt? (pp. 143-167). Bielefeld: Bertelsmann.

Engeström, Y., \& Kerosuo, H. (2007). From workplace learning to interorganizational learning and back: the contribution of activity theory. Journal of Workplace Learning, 19(6),336-342.

Enroth, H. (2014). Governance: The art of governing after governmentality. European Journal of Social Theory, 17(1), 60-76.

European Commission (2012a). State of play of EQF implementation: http://www.europarl.europa.eu/meetdocs/2009_2014/documents/cult/dv/esstu dyeurqualifframewimplem/esstudyeurqualifframewimplemen.pdf. Accessed 10 October 2015.

European Commission (2012b). Rethinking Education: Investing in skills for better socio-economic outcomes. European Commission, Strasbourg: www.cedefop.europa.eu/files/com669_en.pdf. Accessed 18 December 2014. 
European Training Foundation (ETF) (2012). Anticipating and matching skills demand and supply. Synthesis of national reports (from ETF partner countries). Working paper prepared for the ETF by Lorenz Lassnigg. Turin.

Evetts, J. (2003). The sociological analysis of professionalism occupational change in the modern world. International sociology 18(2), 395-415.

Evetts, J. (2011). A new professionalism? Challenges and opportunities. Current Sociology 59(4), 406-422.

Fuller, S. (1995). Is there life for sociological theory after the sociology of Sociology?. The Journal of the British Sociological Association, 29(1), 159166.

García Molina, J.L. (2011). Los Marcos de Cualificaciones, clave de futuro en la modernización de los sistemas de educación y formación professional. Revista del Instituto de Estudios Económicos, 4(3), 219-244.

Gibbons, M., Limoges, C., Nowotny, H., Schwartzmann, S., Scott, P., \& Trow, M. (1994). The new production of knowledge: the dynamics of science and research in contemporary societies. Sage, London.

Hessels, L.K.; van Lente, H. (2008). Re-thinking new knowledge production: A literature review and a research agenda. Research Policy, 37(1), 740-76.

Holford, J., \& Mleczko, A. (2013). Lifelong learning: national policies from the European perspective. In U. Saar, O.B. Ure, \& L. Holford (Eds.), Lifelong learning in Europe: national patterns and challenges (pp. 24-45). Cheltenham: Edward Elgar Publishing.

Lange, B., \& Alexiadou, N. (2007). New Forms of European Union Governance in the Education Sector? A Preliminary Analysis of the Open Method of Coordination. European Educational Research Journal, 6(4), 321-335.

Lassnigg, L. (2012). 'Lost in translation': learning outcomes and the governance of education. Journal of Education and Work, 25(3), 299-330.

Lompscher, J. (1999). Motivation and activity. European Journal of Psychology of Education. 14(1), 11-22.

Lompscher, J. (2004). Lernkultur Kompetenzentwicklung aus kulturhistorischer Sicht: Lernen Erwachsener im Arbeitsprozess. Berlin: Lehmanns Media.

Lægreid, P., Roness, P., \& Rubecksen, K. (2008). Performance information and performancesteering: Integrated system and loose coupling? In W. van Dooren, \& S. van de Walle, (Eds.), Performance information in the public sector: How it is Used. (pp. 346-363), Basingstoke: Palgrave.

Mulderrig, J. (2011). The grammar of governance. Critical Discourse Studies, 8(1), $45-68$.

Normand, R. (2011). Expertise, Networks and Indicators: the construction of the European strategy in education. European Educational Research Journal, 9(3), 407-421.

Nowotny, H., Scott, P., \& Gibbons, M. (2001). Re-thinking Science: Knowledge and the Public in an Age of Uncertainty. Cambridge: Polity Press.

Nowotny, H., Scott, P., \& Gibbons, M. (2003). Introduction: 'Mode 2' Revisited: The New Production of Knowledge. Minerva, 41(3), 179-194.

Papadopoulos, Y. (2010). Accountability and Multi-level Governance: More Accountability, Less Democracy?. West European Politics, 33(5), 1030-1049.

Paulré, B. (2001). Le capitalisme cognitif, un nouveau programme de recherché. Paris: L'harmattan. 
Paster, T. (2005). The New Modes of EU Governance - Combining Rationalism and Constructivism in Explaining Voluntarist Policy Coordination in the EU. Osterreichische Zeitschrift für Politikwissenschaft, 34(2),147-161.

Raffe, D. (2011). The role of learning outcomes in national qualifications frameworks. In S. Bohlinger, \& G. Münchhausen (Eds.), Recognition and validation of prior learning (pp. 87-104). Bonn: BIBB.

Shore, C. (2011). European Governance' or Governmentality? The European Commission and the Future of Democratic Government. European Law Journal, Vol. 17(3), 287-303.

Skarpenes, O. (2007). Kunnskapsparadokser i kunnskapssamfunnet, Norsk Pedagogisk Tidsskrift 1(1), 17-30.

Stehr, N. (2003). The social and political control of knowledge in modern societies. Oxford: Blackwell Publishing.

Souto-Otero, M. (2012). Learning outcomes: good, irrelevant, bad or none of the above?. Journal of Education and Work, 25(3), 249-258. 